\title{
Pengalokasian Risiko Dalam Pembiayaan Proyek Berbasis Sukuk Guna Mewujudkan Kemudahan Berusaha
}

\section{Fadzlurrahman}

Universitas Padjadjaran

fadzlurrahman18001@mail.unpad.ac.id

Lastuti Abubakar

Universitas Padjadjaran

lastuti62abubakar@gmail.com

DOI: 10.23917./jjr.v9i2.8073

Submission
Track:

Received:

2 Mei 2019

Final Revision:

13 Desember 2019

Available online:

17 Januari 2020

Corresponding

Author: Fadzlurrahman fadzlurrahman18001@mail.unpad.ac.id

\section{ABSTRAK}

Tujuan: Artikel ini bertujuan untuk mengetahui dan menganalisis pembiayaan proyek yang dilakukan menggunakan sukuk tabungan seri ST-003 underlaying asset proyek dalam APBN Tahun 2019. Penggunaan sukuk dalam pembiayaan proyek akan berdampak pada kemudahan dalam berusaha di Indonesia dan lebih dikenal dengan EoDB.

Metodologi: Metode yang digunakan dalam penelitian ini termasuk penelitian yang melakukan kegiatan kajian literatur. Sedangkan dalam penyusunan artikel ini menggunakan metodologi pendekatan yuridis normatif, yaitu penelitian hukum yang menitikberatkan pengkajian terhadap data dari mengumpulkan dan mempelajari buku-buku, dokumen-dokumen resmi, hasil-hasil penelitian yang berwujud laporan dan seterusnya guna mendapatkan data sekunder.

Temuan: Adanya Peraturan Pemerintah No. 56 Tahun 2011 tentang Pembiayaan Proyek Melalui Penerbitan Surat Berharga Syariah Negara dan di ikuti dengan peraturan pelaksana dalam Peraturan Menteri No. 113/PMK.08/2013 guna mendorong pertumbuhan ekonomi melalui sektor investasi dan pembangunan infrastruktur. Pembangunan infrastruktur yang baik akan berdampak pada kemudahan dalam berusaha di Indonesia. Ease of Doing Buisness (EoDB) atau yang lazim dikenal dengan kemudahan dalam berusaha di suatu negara merupakan patokan terhadap suatu negara bagi investor yang akan menanamkan modalnya di negara tujuan investasinya. Lancarnya suatu pembiayaan proyek tidak terlepas dari alokasi risiko yang baik. 
Kegunaan: Penelitian ini bermanfaat dalam mengalokasikan risiko dalam pembiayaan proyek yang dilakukan menggunakan sukuk tabungan seri ST-003 underlaying asset proyek dalam APBN Tahun 2019.

Kebaruan/Orisinalitas: Risiko dalam pembiayaan proyek merupakan bentuk dari prinsip kehati-hatian dalam pengelolaan dana dalam investasi yang di sediakan oleh pemerintah guna pembangunan infrastruktur. Dana yang dikeluarkan dari sukuk merupakan dana yang dihimpun dari masyarakat dan negara sebagai pengelola dirasa perlu berhati-hati dalam pengelolaannya.

Keywords: Pembiayaan Proyek, Sukuk, EoDB, Alokasi Risiko

\section{PENDAHULUAN}

Perkembangan pembiayaan proyek terus mengalami perkembangan salah satu pembiayaan proyek yang paling terkenal adalah pembiayaan Terusan Suez di Mesir yang bekerja sama dengan Anglo-French Concessionaire pada tahun 1898. Sebagai pihak sponsor Anglo-French Concessionaire berhak membangun terusan, mengoptimalkan, mengoperasikan, dan merawat selama 99 tahun, dibandingkan sekarang pengelolaan proyek oleh asing cuma selama 30 tahun. Perkembangan pembiayaan proyek semakin pesat terbukti setelah diterapkan oleh negara maju seperti Jepang untuk pembiayaan kereta cepat TokyoOsaka pada tahun 1970 dan di Amerika reformasi pembangkit listrik pada tahun 1970. Di negara-negara berkembang pembiayaan proyek digunakan oleh pemerintah untuk membangun proyek fasilitas umum seperti di sektor listrik, transportasi, sumber daya alam, properti, telekomunikasi dan industri.

Ekonomi syariah atau dikenal juga dengan ekonomi Islam sebagaimana dikemukakan oleh Afzalur Rahman adalah sebuah sistem ekonomi yang berbeda dengan sistem kapitalisme dan sosialisme(Hamid, 2006). Sukuk merupakan instrumen penting pembiayaan proyek dalam keuangan ekonomi syariah. Tercatat sejak tanggal 21 Desember 2018 mencapai Rp. 22,52 Triliun pembiayaan proyek yang menggunakan sukuk sebagai pembiayaan. Kementerian Keuangan berpendapat jumlah ini meningkat sekitar 34,36 persen dari realisasi tahun lalu sebesar Rp. 16,76 Triliun. Peningkatan terjadi sejak tahun 2013 sejumlah Rp. 800 Miliar, tahun 2014 sebesar Rp. 1,57 Triliun, kemudian 2015 sebesar Rp. 7,17 Miliar, dan 2016 sebesar Rp 13,67 Miliar. Sukuk sendiri merupakan pembiayaan proyek berdasarkan prinsip 
syariah yang ditawarkan oleh pemerintah guna menghimpun dana dari masyarakat. Akad yang digunakan dalam investasi sukuk ini adalah wakalah ini berarti para pemegang sukuk menyerahkan kekuasaan pengelolaan uang kepada pemerintah sebagai pengganti dalam menjalankan proyek. Sekarang pemerintah Indonesia telah mengeluarkan Sukuk Tabungan Seri ST-003 dengan underlaying asset proyek dalam APBN Tahun 2019 dan Baran Milik Negara berupa tanah dan/atau bangunan(Kementrian Keuangan Republik Indonesia, 2019).

Penggunaan sukuk sebagai pembiayaan proyek akan meringankan baban Anggaran Pendapatan Belanja Negara (APBN) yang bisa digunakan dan dimanfaatkan sebagai menunjang program lain. Peningkatan dalam jumlah pembiayaan melalui sukuk tetapi terjadi penurunan dalam proyek yang dibiayai pada tahun 2017 sekitar 590 proyek yang dibiayai oleh sukuk sekarang pada tahun 2018 sebanyak 587 proyek yang dibiayai. Pemerintah telah mengeluarkan Peraturan Pemerintah No. 56 Tahun 2011 tentang Pembiayaan Proyek Melalui Penerbitan Surat Berharga Syariah Negara dan di ikuti dengan peraturan pelaksana dalam Peraturan Menteri No. 113/PMK.08/2013 guna mendorong pertumbuhan ekonomi melalui sektor investasi dan pembangunan infrastruktur. Pembangunan infrastruktur yang baik akan berdampak pada kemudahan dalam berusaha di Indonesia. Ease of Doing Buisness (EoDB) atau yang lazim dikenal dengan kemudahan dalam berusaha di suatu negara merupakan patokan terhadap suatu negara bagi investor yang akan menanamkan modalnya di negara tujuan investasinya. Semakin rendah peringkat negara maka semakin mudah berinvestasi di negara tersebut. Penilaian EoDB dilakukan oleh Bank Dunia ini mengambil penilaian dari kemudahan berinvestasi di negara tersebut melalui kriteria yang diterapkan oleh bank dunia. Saat ini posisi Indonesia berada pada peringkat 73 dari 190 Negara dan kota terpilih(World Bank Group, 2019). Ini dirasa sudah cukup bagi ini Indonesia yang tidak ingin mayoritas saham, kepemilikan perusahaan dan pengolahan sumber daya dimiliki asing dengan mengutamakan pengolahan dari, oleh, dan untuk kemakmuran rakyat, tetapi Indonesia punya cita-cita untuk meningkatkan peringkat menjadi 40 besar. Cita-cita tersebut tidak mudah untuk dijalankan, dalam pelaksanaannya risiko dalam pembiayaan proyek berbentuk sukuk bisa saja terjadi seperti gagal bayar pembayaran imbalan dan pembayaran kembali saat jatuh tempo, risiko terkait penyelesaian proyek, risiko terkait dengan operasional proyek, risiko yang terkait finansial dan risiko lain terkait sosial politik dan lingkungan. Pengalokasian risiko merupakan cara yang tepat dalam mengatasi risiko dalam pembiayaan proyek berbasis sukuk. Identifikasi, analisis, mitigasi, alokasi risiko dan membuat perjanjian antara pihak yang 
memiliki kemampuan terbaik dalam mengendalikannya. Penelitian ini akan memaparkan bagaimana cara mengalokasikan risiko dari pembiayaan proyek berbasis sukuk bagaimana peran sukuk dalam pembiayaan proyek yang anak mendorong kemudahan berusaha di Indonesia.

\section{METODE PENELITIAN}

Metode yang digunakan dalam penelitian ini termasuk penelitian yang melakukan kegiatan kajian literator yakni dengan menggunakan buku, artikel, internet dan pendapat para ahli ekonomi Islam sebagai bahan yang dipakai untuk menghimpun data-data atau sumbersumber yang berhubungan dengan topik yang diangkat dalam penelitian. Penelitian ini juga mencari referensi melalui teori yang relevan dengan kasus dan permasalahan yang diteliti(Hastuti, 2018).

\section{HASIL DAN PEMBAHASAN}

\section{Sukuk Sebagai Instrumen Pembiayaan Proyek}

Pembiayaan proyek dengan instrumen sukuk merupakan pembiayaan terhadap suatu proyek yang nanti pengembalian dananya dilakukan dengan membagi hasil dari pendapatan yang didapat selama proyek berjalan dan di akhir jatuh tempo pengembalian sukuk yang diberikan pada negara. Berdasarkan UU No. 19 Tahun 2008 Tentang Surat Berharga Syariah Negara sukuk adalah surat berharga yang diterbitkan negara sebagai bukti atas bagian penyertaan terhadap aset SBSN, baik dalam mata uang rupiah maupun valuta asing. Fatwa DSN-MUI No. 69/DSN-MUI/VI/2008 Sukuk harus didasarkan pada prinsip syariah dalam kepemilikan aset SBSN. OJK juga mengutarakan pengertian Sukuk dalam POJK No. 18/POJK.04/2015 bukti kepemilikan tidak terpisahkan dengan aset yang mendasarinya. Kesimpulan yang didapat dari pengertian dari ketiga regulasi tersebut adalah surat berharga yang diterbitkan oleh negara sebagai bukti kepemilikan aset SBSN yang sesuai dengan prinsip syariah dan tidak dapat dipisahkan dengan aset yang mendasarinya.

Merujuk pada Peraturan Pemerintah No. 56 Tahun 2011 Tentang Pembiayaan Proyek Melalui Penerbitan Surat Berharga Syariah Negara (SBSN), sukuk dapat dikeluarkan oleh pemerintah melalui menteri guna membiayai suatu proyek melalui Perusahaan Penerbit SBSN. Proyek-proyek tersebut sebelumnya harus telah dialokasikan dalam APBN baik yang sedang dilaksanakan atau akan dilaksanakan. Proyek tersebut dapat berupa pembangunan 
infrastruktur, penyediaan sarana pelayanan umum, pemberdayaan industri dalam negeri dan yang lain lain sesuai dengan kebijakan strategis dari pemerintah yang berkuasa.

Kementerian yang ditunjuk sebagai pemeriksa proyek harus melaksanakan proyek sesuai dengan ketentuan syariah sebagaimana yang diatur dalam fatwa DSN-MUI. Sebagai pemeriksa proyek hal yang harus diperhatikan adalah perencanaan dan pengusulan proyek, pelaksanaan proyek, pengawasan dan pemanfaatan, serta pengelolaan objek pembiayaan. Peraturan pelaksanaan dibuat dalam Peraturan Menteri Keuangan No. 113/PMK.08/2013.

Hukum positif di Indonesia telah mebuat aturan tentang surat berharga syariah ini termasuk sukuk di dalamnya. Pengaturan mengenai sukuk dibuat oleh Dewan Syariah Nasional Majelis Ulama Indonesia sebagai lembaga yang berwenang dalam melegitimasi kebijakan pemerintah dalam hal syariah. DSN-MUI mengeluarkan Fatwa No. 32/DSNMUI/IX/2002 yang menyebutkan sukuk sebagai surat berharga jangka panjang yang didasari prinsip syariah yang dikeluarkan oleh emiten untuk pemegang obligasi syariah untuk membayar pendapatan dari obligasi syariah dapat berupa bagi hasil/margin dan fee serta di akhir masa/jatuh tempo perjanjian membayar kembali obligasi.

Sukuk merupakan sertifikat yang memberikan atau mempresentasikan hak kepemilikan yang tidak terbagi kepada pemegang aset, manfaat, jasa atau aset tertentu, proyek atau kegiatan investasi tertentu(Abubakar \& Handayani, 2017). dari makna tersebut maka jelas lah bahwa pembiayaan proyek dari dapat juga berasal dari sukuk yang dikeluarkan oleh pihak pemegang proyek, sponsor dalam sukuk adalah sebagai pihak yang memegang surat berharga syariah atau sukuk. Negara sebagai pihak yang akan membangun proyek juga dapat mengeluarkan sukuk ini terdapat dalam Undang-Undang No. 19 Tahun 2008 Tentang SBSN atau Sukuk Negara. Sukuk Negara yang diterbitkan oleh pemerintah haruslah berdasarkan prinsip syariah sebagai bukti penyertaan terhadap aset SBSN dalam bentuk Rupiah dan valuta Asing. Proyek yang akan dibiayai oleh sukuk harus terdapat dalam APBN termasuk membiayai infrastruktur non profit dan diperuntukkan bagi pelayanan publik guna menyejahterakan rakyat. Proyek ini harus merupakan proyek yang direncanakan oleh pemerintah pusat guna pembangunan jangka menengah dengan kriteria yang ditetapkan oleh Bappenas.

Di Indonesia terdapat enam macam jenis sukuk negara yaitu : a) Sukuk ritel adalah sukuk yang dijual kepada individu, b) sukuk valas, sukuk yang diterbitkan pasar modal internasional dalam bentuk valuta asing, c) sukuk dana haji Indonesia, diterbitkan khusus pada sukuk 
negara dari dana haji yang dikumpulkan, d) Sukuk seri IFR penerbitan dipasar perdana dalam negeri yang di dominasi rupiah, e) Surat Perbendaharaan Negara Syariah (SPNS), yang diterbitkan dengan tenor kurang dari satu tahun, f) Proyek didasarkan Sukuk, yang diterbitkan dengan menggunakan Underlying Asset dalam suatu proyek(Datuk, 2014).

Dari tahun 2015-2019 Indonesia dihadapkan dengan kesenjangan pembiayaan infrastruktur yang tercantum dalam RPJMN 2015-2019. Kesenjangan tersebut sebesar Rp. 922 Triliun yang perlu di tutupi dengan sumber pembiayaan lain seperti sukuk(Abidin, 2016). Orientasi SBSN menurut Irfan Syauqi Beik adalah untuk sektor padat karya, optimalisasi potensi daerah, pembangunan infrastruktur, seperti transportasi, telekomunikasi, energi, dan lain-lain. Hal ini sangat penting mengingat infrastruktur di Indonesia masih tertinggal dibandingkan negara-negara lain seperti Malaysia dan Thailand. Secara ekonomi, multiplier effect yang dapat dihasilkan dari pembangunan infrastruktur ini akan sangat besar(Beik, 2019).

Pada tanggal 27 Februari 2019 Pemerintah Indonesia menerbitkan Sukuk Tabungan Seri ST-003. Sukuk tabungan jenis ini adalah sukuk tanpa warkat dan tidak dapat diperdagangkan di pasar sekunder dengan menggunakan akad wakalah. Target penerbitan sukuk jenis ini adalah untuk investor individu Warga Negara Indonesia. Hal yang unik dalam sukuk Seri ST003 ini adalah akad wakalah yang digunakan. SBSN Wakalah sendiri diatur dalam Fatwa No. 95/DSN-MUI/VII/2014 tentang SBSN Wakalah, yang sebelumnya SBSN menggunakan Akad Ijarah, Mudharabah,Musyarakah dan Istisha'. Konsep dari SBSN Wakalah ini sendiri atas dasar kesepakatan bersama antara investor dan perusahaan penerbit SBSN Indonesia di mana investor setuju untuk menugaskan (wakalah) dana investasi kepada perusahaan SBSN Indonesia sebagai wali amanat untuk kegiatan investasi yang menghasilkan keuntungan. Perusahaan penerbit SBSN menyatakan kesangupannya dalam mengelola dana investasi sukuk yang bertindak sebagai wakil dari pengelolaan dana investasi. Investasi dari penerbitan sukuk tabungan digunakan untuk pembelian aset SBSN (Underlying Asset). Pembelian aset harus menggunakan prinsip syariah atau menggunakan akad Bai'. Selanjutnya akan mengadakan perjanjian dengan pengadaan proyek untuk membeli proyek dari pemerintah. Atas dasar perjanjian proyek maka perusahaan SBSN akan memberikan kewenangan pada pemerintah untuk melakukan pengadaan proyek dalam rangka pengadaan objek akad ijarah sesuai dengan jenis dan spesifikasi tertentu. Dalam perjanjian perusahaan penerbit SBSN Indonesia dengan pemerintah Indonesia menggunakan akad Ijarah yang mana Perusahaan 
Penerbit SBSN selaku pemberi sewa dan pemerintah sebagai penerima sewa dengan ketentuan objek Ijarah yang digunakan sebagai kompensasi dari imbalan jasa pemeliharaan atas objek Ijarah.

Perusahaan Penerbit SBSN Indonesia memberikan kuasa kepada Pemerintah untuk memelihara obyek Ijarah yang telah disewa dalam Akad Ijarah berdasarkan Akad Wakalah Atas Pemeliharaan Obyek Ijarah. Pernyataan menjual dari Perusahaan Penerbit SBSN Indonesia dimana Perusahaan Penerbit SBSN Indonesia hanya akan menjual Aset SBSN kepada Pemerintah baik dalam hal akan melakukan Early Redemption atau pada saat pengakhiran Akad Ijarah, dengan harga yang disepakati oleh Perusahaan Penerbit SBSN Indonesia dan Pemerintah. Pernyataan membeli dari Pemerintah di mana Pemerintah akan membeli Aset SBSN yang dijual oleh Perusahaan Penerbit SBSN Indonesia dalam hal Early Redemption atau pada saat pengakhiran Akad Ijarah, dengan harga yang disepakati oleh Pemerintah dan Perusahaan Penerbit SBSN Indonesia ini tertuang dalam Memorandum Informasi Sukuk Tabungan Seri ST-003 yang diterbitkan oleh Kementerian Keuangan Republik Indonesia Pada Tanggal 1 Februari 2019.

Sukuk Seri ST-003 diterbitkan pada tanggal 27 Februari 2019 dan jatuh tempo pada tanggal 10 Februari 2021. Nilai nominal ST-003 yang akan diterbitkan akan ditetapkan oleh Pemerintah berdasarkan hasil pelaksanaan penjualan. Nilai Nominal per unit ST-003 ditetapkan sebesar Rp1.000.000,00 (satu juta rupiah). Imbalan berupa sewa yang jumlah pembayarannya bersifat mengambang (disesuaikan setiap tiga bulan) dengan Imbalan minimal (floating with floor). Sukuk jenis ini tidak dapat diperdagangkan atau dialihkan. Underlying Asset dari sukuk Seri ST-003 adalah; Proyek dalam APBN tahun 2019 dengan nilai dan spesifikasi yang telah ditetapkan oleh Menteri Keuangan, Barang Milik Negara (BMN) berupa tanah dan/atau bangunan yang telah ditetapkan oleh Menteri Keuangan, kemudian Menteri Keuangan menetapkan rincian Proyek dan BMN tersebut di atas yang akan digunakan sebagai Aset SBSN dalam rangka penerbitan ST-003.

Keuntungan menggunakan sukuk sebagai instrumen dalam pembiayaan proyek adalah sebagai berikut; 1) pembayaran dan nilai nominal ST-003 dijamin oleh negara berdasarkan Undang-Undang SBSN dan Undang-Undang APBN setiap tahunnya, sehingga Sukuk Tabungan seri ST-003 kecil kemungkinan gagal bayar, 2) Pada saat diterbitkan, Imbalan ST003 ditawarkan lebih tinggi dibandingkan rata-rata tingkat bunga deposito bank Badan Usaha Milik Negara, 3) Imbalan mengambang dengan jaminan kupon minimal (floor) sampai 
dengan Tanggal Jatuh Tempo, 4) Imbalan ST-003 dibayar setiap bulan, 5) Terdapat fasilitas Early Redemption tanpa dikenakan Redemption Cost. 6) Memberikan kesempatan kepada masyarakat untuk turut serta mendukung pembiayaan pembangunan nasional, 7) Kemudahan akses untuk melakukan Pemesanan Pembelian dan pengajuan Early Redemption melalui Sistem Elektronik, 8) Memberikan akses kepada investor untuk berpartisipasi dalam aktivitas pasar keuangan dengan cara dan metode yang tidak bertentangan dengan prinsip-prinsip syariah.

\section{Risiko dan Pengalokasian Risiko dalam Pembiayaan Proyek Berbasis Sukuk}

Risiko dalam pembiayaan proyek dapat dikurangi jika para pihak sebelumnya melakukan identifikasi, analisis, mitigasi dan alokasi risiko. Risiko sebaiknya di alokasikan dalam bentuk perjanjian antara pihak yang memiliki kemampuan terbaik dalam mengendalikannya. Semua pihak yang terlibat dalam pembiayaan proyek akan bertanggung-jawab terhadap risiko yang dialami. Kontraktor akan menanggung risiko yang berkaitan dengan konstruksi dan proyek yang sedang dikerjakan. Operator akan bertanggung-jawab seputar kegiatan operasional proyek, bahkan pemerintah akan bertanggung-jawab terhadap risiko politik dalam bentuk pergantian pemerintahan, gonjang-ganjing politik dan kestabilan mata uang. Ada beberapa risiko dalam pembiayaan berbasis sukuk dan pengalokasiannya akan dijelaskan sebagai berikut

a) Risiko Gagal Bayar

Risiko gagal bayar (default risk) adalah risiko apabila investor tidak dapat memperoleh pembayaran dana yang dijanjikan oleh penerbit pada saat produk investasi jatuh tempo baik Imbalan dan Nilai Nominal. Mengingat Sukuk Seri ST003 merupakan sukuk yang diterbitkan oleh pemerintah sebagai instrumen pasar modal yang bebas risiko (risk free instrument) karena pembayaran Imbalan dan Nilai Nominal ST-003 dijamin oleh Pemerintah berdasarkan Undang-Undang SBSN dan Undang-Undang APBN. Terkadang risiko gagal bayar mungkin terjadi. Guna menyelamatkan proyek dari gagal bayar maka dibuat perjanjian dengan pembeli (Offtake agreement), perjanjian ini untuk memberikan dan penjualan jangka panjang pada pembeli yang setuju untuk membeli output dari proyek. Perjanjian dengan pembeli terbagi dalam ; 1) perjanjian pembelian di mana salah satu pihak setuju untuk membeli hasil output yang dihasilkan secara berkala dengan kesepakatan harga satuan yang ditetapkan misalnya dalam pembangkit listrik PLN sebagai pembeli 
tenaga listrik menjamin pembelian output dengan jumlah dan harga yang disepakati, 2) mengikat pembeli untuk tetap membayar output dalam situasi atau keadaan apa pun. Ini merupakan ketetapan yang mengharuskan pihak pembeli untuk membeli output dengan harga dan kapasitas yang telah disepakati, 3) pihak pembeli akan bertindak sebagai perusahaan induk yang akan membeli output dan menanggung defisit biaya yang dialami oleh SPV sebagai contoh PT.PLN sebagai perusahaan induk yang membutuhkan pengaliran listrik ke lokasi sektor industri dan anak perusahaan sebagai SPV akan menjalankan proyek yang dibentuk untuk membuat instalisasi listrik akan mengadakan perjanjian dengan perusahaan induknya untuk mengaliri pasokan listrik setiap bulan dengan tarif tertentu, 4) pemenuhan biaya SPV ditanggung secara profesional dengan mengharuskan setiap pemegang saham untuk membayar biaya yang dikeluarkan oleh SPV secara profesional sesuai bagian masing masing. Kontrak ini akan menutupi biaya operasional administrasi pemeliharaan dan pengembalian modal ekuitas, 5) SPV menetapkan tarif untuk mengelola bahan baku dari sponsor dan mendistribusikan kembali pada sponsor, 6) jika terdapat banyak pembeli, maka SPV dapat mengadakan perjanjian dengan para pembeli untuk menanggung gagal bayar salah satu pembeli oleh pembeli lain.

b) Risiko Likuiditas

Risiko likuiditas (liquidity risk), adalah kesulitan dalam menjual ST-003 sebelum jatuh tempo apabila investor memerlukan dana tunai. ST-003 memiliki risiko likuiditas karena tidak dapat diperdagangkan dan dialihkan. Namun ST-003 dapat dicairkan sebelum jatuh tempo dengan memanfaatkan fasilitas Early Redemption.

c) Risiko Tingkat Imbalan

Risiko tingkat Imbalan/Kupon, adalah risiko berkurangnya Imbalan yang diterima investor karena adanya perubahan Tingkat Imbalan Acuan. ST-003 tidak memiliki risiko tingkat Imbalan/Kupon karena tingkat Imbalan ST-003 yang ditetapkan pada saat penerbitan merupakan jaminan tingkat Imbalan/Kupon minimal (floor) yang akan diterima investor sampai dengan jatuh tempo.

d) Risiko dengan Kontraktor

Risiko dengan kontraktor yang menyebabkan hambatan dalam jalannya proses proyek. Sebelum pengalokasian risiko lebih baik kita mengenal risiko yang dialami kontraktor dalam menjalankan proyek ; a) kekurangan biaya di saat proyek sedang 
dijalankan, b) keterlambatan proyek, c) dan spesifikasi yang diinginkan tidak tercapai. Dengan mengetahui risiko tersebut maka dalam perjanjian harus dengan jelas mengatur tentang jadwal penyelesaian pekerjaan, spesifikasi, target timeline yang harus diselesaikan, dan kompensasi jika terjadi keterlambatan. Honor kontraktor yang tetap akan mengembangkan performa di lapangan. Jika proyek membutuhkan banyak kontraktor dalam pengerjaannya maka sebaiknya ditunjuk salah satu kontraktor sebagai pemimpin guna mempermudah komunikasi.

e) Risiko dengan Supplier

Alokasi risiko dengan supplier yang akan menanggung risiko berkaitan dengan bahan baku, harga, distribusi dan spesifikasi kualitas. Kontrak yang akan dibuat dengan supplier perlu ada pernyataan untuk membeli bahan baku dengan harga yang telah disepakati bersama. Apabila terjadi pemberhentian sementara terhadap proyek maka SPV harus memberitahu supplier agar tidak ada kerugian yang akan didapatkan oleh supplier selama pasokan minimum tahunan dapat dipenuhi. Jika supplier tidak mampu memasok bahan baku sesuai kesepakatan makan supplier harus bertanggungjawab dengan mencari bahan baku ke market atau membayar kompensasi kepada sponsor.

f) Risiko dengan Operator

Alokasi risiko dengan operator yang menangung segala akibat dari operasional dari proyek. Sebelum pelaksanaan proyek dilakukan maka terlebih dahulu sponsor memerlukan persetujuan dari pihak pemerintah menyangkut masalah lingkungan dan keselamatan kerja. Selama kegiatan operasional proyek hal yang perlu diperhatikan adalah suplai dan bahan baku, permintaan atas produk dan jasa, pendistribusian produk, serta kualitas produk yang dihasilkan. Tiga poin pertama memerlukan kerja sama antara supplier, pembeli dan distribusi. Dalam poin yang keempat adanya standardisasi yang harus dicapai oleh operator dengan mencantumkan dalam kontrak. Kriteria kontrak yang dalam hubungan dengan operator; a) operator harus diberikan inisiatif yang selayaknya guna dalam menjalankan proyek dengan efisien dan mengoptimalkan keuntungan SPV, b) operator dapat dikenakan penalti jika operasional proyek tidak sesuai dengan apa yang diminta, c) Perusahaan Penerbit Sukuk dapat mengganti atau menunjukkan usulan untuk dapat pengantihan operator yang tidak produktif dan buruk kinerjanya, d) jika operator mengupayakan anak 
perusahaan dari sponsor atau hubungan lain dengan sponsor maka perlu adanya kontrak yang jelas antara sponsor dan operator.

\section{Sukuk dalam Membangun Infrastruktur Guna Kemudahan Berusaha di Indonesia}

Pembangunan yang dibiayai oleh sukuk dapat dilihat pada pembangunan jalan tol, pembangunan perumahan layak huni dan rumah susun untuk penduduk miskin dan peningkatan fasilitas di bandara dan pelabuhan. Sukuk juga akan memeningkan posisi Indonesia di pasar syariah global guna menarik investor muslim untuk berinvestasi. Saat ini campur tangan pemerintah diperlukan dalam pembangunan infrastruktur supaya maksimal terutama untuk pemberdayaan BUMN yang merupakan pembeli sukuk terbesar dibandingkan obligasi konvensional(Abubakar \& Handayani, 2017). Kepastian Hukum dalam berinvestasi merupakan hal menentukan penerbitan sukuk itu menghasilkan return atau tidak kepada investor. Investor akan merasa terlindungi jika terdapat regulasi yang baik.

Adanya infrastruktur yang baik akan memengaruhi kepada kemudahan dalam berusaha atau Easy of Doing Busisness (EoDB). Awal mula EoDB sendiri bermula sejak Bank Dunia mengenalkan program ini, $E o D B$ berpatokan pada indeks kemudahan berbisnis dari beberapa negara dan kota di seluruh dunia. Peringkat yang tinggi menunjukkan peraturan untuk berbisnis yang lebih baik/sederhana prosesnya. Indeks ini dipakai oleh seluruh dunia dan menjadikan patokan dalam berinvestasi dalam menanamkan modalnya. Ada sebelas penilaian yang digunakan dalam $E O D B$ ini. Sebelas indikator tersebut diantaranya adalah memulai usaha (starting a business), perizinan terkait mendirikan bangunan (dealing with construction permit), penyambungan listrik (getting electricity), pendaftaran properti (registering property), akses perkreditan (getting credit), perlindungan terhadap investor minoritas (protecting minority investors), pembayaran pajak (paying taxes), perdagangan lintas negara (trading across border), pengaturan tenaga kerja (labor market regulation), penegakan kontrak (enforcing contracts), dan penyelesaian perkara kepailitan (resolving insolvency).

Penilaian dalam EoDB menggunakan penilaian terhadap regulasi bisnis dan penerapan bisnis tersebut terhadap 190 negara dan kota-kota di seluruh dunia yang tepilih hasilnya dibuat dalam bentuk laporan. Hasil laporan ini berupa data tentang kemudahan berusaha dan rekomendasi untuk meningkatkan pelaksanaan kemudahan dalam berusaha. Semakin tinggi peringkat dari hasil laporan tersebut semakin baik negara tersebut untuk berinvestasi. 
Listrik merupakan salah satu kebutuhan yang sangat penting dalam melakukan berusaha terutama terkait tempat yang akan digunakan dalam berusaha. Penyambungan listrik merupakan indikator yang juga di nilai oleh bank dunia. Dalam mendapatkan sambungan listrik asumsi bangunan yang digunakan oleh Bank Dunia adalah(EoDB Ekon, 2019) 1) hanya untuk sambungan listrik bangunan gedung berukuran minimal $929 \mathrm{~m} 2$ (luas tanah 1.300,6 $m 2)$, 2) bangunan dan baru pertama kali tersambung listrik, 3) listrik yang tersambung dengan daya $140 \mathrm{KVA}$, 4). Bank Dunia menetapkan kriteria dalam penilaiannya untuk bidang penyambungan listrik berdasarkan jumlah prosedur yang diperlukan untuk mendapatkan sambungan listrik, waktu yang diperlukan untuk melengkapi sambungan tersebut, biaya yang dibutuhkan di luar PPN, keandalan pasokan dan trasparansi indeks tarif. Hasil survei tahun 2017 indikator penyambungan listrik ini naik dari peringkat 49 yang sebelumnya peringkat 61 pada EoDB tahun 2016 dengan usaha pemerintah mempersingkat dalam pengajuan sambungan baru mulai dengan permohonan dan pembiayaan sambungan baru yang dilaksanakan hanya dalam waktu 1 (satu) hari, pemeriksaan instalasi pelanggan untuk SLO dalam waktu 3 hari (tiga) hari, pembangunan jaringan dan pemasangan meter hanya dalam 21 hari sehingga membutuhkan waktu guna instalasi baru selama 25 hari.

Guna tercapainya pasokan listrik yang cukup untuk berinvstasi di Indonesia pemerintah melalui Kementrian Energi dan Sumber Daya Mineral mengeluarkan KEPMEN No. 2628 K/21/MEM/2008 Tentang Rencana Umum Kelistrikan Nasional kemudian yang disahkan dalam Kepmen No. 5899 K/20/MEM/2016 Tentang Pengesahaan Rencana Usaha Penyediaan Tenaga Listrik PT. PLN tahun 2016 s.d 2025. Cita-cita dari KEPMEN tersebut untuk melakukan percepatan pembangunan infrastruktur kelistrikan termasuk program pembangkit 35.000 MW dan jaringan transmisi sepanjang 46.000 KM.

Potensi sukuk dalam membantu proyek penyediaan listrik bagi masyarakat dalam kemudahan usaha sangatlah besar. Di atas telah dijelaskan potensi BUMN terutama PLN sebagai penyedia kelistrikan berpeluang mengeluarkan sukuk terbesar, sayangnya dalam pelaksanaan PLN lebih cendrung memilih obligasi konvensional. Ini dapat dilihat dalam Lampiran Kepmen No. 5899 K/20/MEM/2016 Tentang Pengesahan Rencana Usaha Penyediaan Tenaga Listrik PT. PLN tahun 2016 s.d 2025. Di dalam rencana tersebut menyebutkan pinjaman pemerintah dapat melalui rekening dana investasi, obligasi nasional maupun internasional, pinjaman komersial perbankan lainnya serta hibah dari luar negeri. Pembangunan ini juga akan mengalami risiko keterlambatan proyek-proyek PLN diantaranya 
akibat kurangnya dana yang diupayakan oleh PLN, baik yang berasal dari internal maupun pinjaman/obligasi.

Infrastruktur menyerupakan fasilitas yang berguna untuk memperlancar mobilisasi perputaran barang dan jasa yang dihasilkan oleh masyarakat. Dengan pembangunan infrastruktur yang semakin meningkat maka memperbaiki peringkat kemudahan berusaha dan meningkatkan daya saing nasional dalam Masyarakat Ekonomi Asean, penciptaan lapangan pekerjaan dan ekspor. Saat ini dalam Peraturan Pemerintah No. 24 Tahun 2018 Tentang Pelayanan Perizinan Berusaha Terintegrasi Secara Elektronik. Maka dengan berlakunya PP tersebut perizinan proyek yang akan dilaksanakan oleh negara ataupun pihak swasta harus terintegrasi secara elektronik atau Online Single Submission (OSS)(Setiadi, 2018). Philip Kotler pernah menyebutkan, "Internet (Online) memberikan jalan yang begitu luas bagi pemasar untuk membangun hubungan dengan pelanggan(Kotler, 2002). Perbaikan perizinan pendaftaran proyek ini akan memudahkan dalam menjalankan proyek mengingat pembiayaan proyek membutuhkan waktu, biaya dan proses yang panjang.

Sebagai proyek berskala besar perlu pengurusan IMB, dengan adanya IMB dapat menjadi poin penilaian sendiri dalam indikator kemudahan berusaha. SPV yang sebagai pelaksana proyek juga akan memengaruhi penilaian setidaknya dalam indikator pendaftaran bangunan, perizinan terkait mendirikan bangunan, dan penegakan kontrak.

Ada peluang yang besar bagi sukuk sebagai suatu pembiayaan proyek dengan dukungan dari UU No. 19 Tahun 2008 Tentang Surat Berharga Negara atau Sukuk Negara. Dengan landasan tersebut pemerintah dapat menerbitkan Sukuk Negara dengan Barang Milik Negara (BMN) sebagai underlaying asset guna membangun proyek proyek yang akan meningkatkan peringkat Indonesia dalam EoDB. Melalui peraturan ini pemerintah dapat mengatur komposisi penerbitan Sukuk Negara untuk pembiayaan proyek, sehingga hasil penerbitan Sukuk Negara dapat diarahkan untuk mendorong percepatan pembangunan infrastruktur(Hariyanto, 2016).Percepatan pembangunan infrastruktur dalam bidang pembangunan jalan, bandara, rel kereta api, pelabuhan, kelistrikan, telekomunikasi dan yang lain-lain membutuhkan dana yang sangat besar dalam waktu yang singkat. Sukuk dapat memberikan ruang fiskal bagi pemerintah dalam membantu penerimaan negara untuk sumber dana proyek infrastruktur ini. Tingkat korupsi, regulasi, situasi sosial politik dan faktor-faktor eksternal lainnya akan memengaruhi penjualan sukuk. Pemerintah seharusnya memperhatikan variabel-variabel tersebut guna menciptakan akselerasi dalam pertumbuhan ekonomi. Dengan 
dukungan sukuk pembangunan infrastruktur akan mendorong negara ke arah pertumbuhan ekonomi.

\section{KESIMPULAN}

Sukuk dapat dikeluarkan oleh pemerintah melalui menteri guna membiayai suatu proyek melalui Perusahaan Penerbit SBSN. Proyek-proyek tersebut sebelumnya harus telah dialokasikan dalam APBN baik yang sedang dilaksanakan atau akan dilaksanakan. Proyek tersebut dapat berupa pembangunan infrastruktur, penyediaan sarana pelayanan umum, pemberdayaan industri dalam negeri dan yang lain lain sesuai dengan kebijakan strategis dari pemerintah yang berkuasaSukuk Tabungan Seri ST-003 yang baru-baru ini dikeluarkan pemerintah guna mencegah kesenjangan pembiayaan infrastruktur yang tercantum dalam RPJMN 2015-2019. Pembiayaan Proyek yang berbasis sukuk juga akan menimbulkan resiko dalam pelaksanaannya. Alokasi risiko menjadi penting dalam menjalankan proyek. Adanya pembagian risiko yang dilakukan dengan membagi risiko pada pihak yang dianggap memiliki kemampuan terbaik dalam mengatasi risiko. Risiko gagal bayar misalnya melihat Sukuk Seri ST-003 merupakan sukuk yang diterbitkan oleh pemerintah sebagai instrumen pasar modal yang bebas risiko (risk free instrument) karena pembayaran Imbalan dan Nilai Nominal ST003 dijamin oleh Pemerintah berdasarkan Undang-Undang SBSN dan Undang-Undang APBN. Selain itu Sukuk Seri ST-003 juga memiliki risiko likuiditas karena tidak dapat diperdagangkan dan dialihkan. Namun ST-003 dapat dicairkan sebelum jatuh tempo dengan memanfaatkan fasilitas Early Redemption. Risiko dengan supplier, operator dan kontraktor dapat di alokasikan dengan membuat perjanjian pengalokasian risiko.

Adanya infrastruktur yang baik akan mempengaruhi kepada kemudahan dalam berusaha atau Easy of Doing Busisness (EoDB). Dengan terlaksananya proyek infrastruktur akan mendorong Indonesia mencapai cita-cita 40 besar peringkat EoDB. Potensi sukuk dalam membantu proyek penyediaan listrik bagi masyarakat dalam kemudahan usaha sangatlah besar. Di atas telah dijelaskan potensi BUMN terutama PLN sebagai penyedia kelistrikan berpeluang mengeluarkan sukuk terbesar, sayangnya dalam pelaksanaan PLN lebih cendrung memilih obligasi konvensional. Kepastian Hukum dalam berinvestasi merupakan hal menentukan penerbitan sukuk itu menghasilkan return atau tidak kepada investor. Investor akan merasa terlindungi jika terdapat regulasi yang baik. 


\section{KEPUSTAKAAN}

Abidin, M. (2016). Analisis Investasi Dana Haji dalam Pembiayaan Infrastruktur dan Peningkatan Kualitas Penyelenggaraan Ibadah Haji. Harmoni, 15(2).

Abubakar, L., \& Handayani, T. (2017). Kesiapan Infrastruktur Hukum Dalam Penerbitan Sukuk (Surat Berharga Syariah) Sebagai Instrumen Pembiayaan Dan Investasi Untuk Mendorong Pertumbuhan Pasar Modal Syariah Indonesia. Jurnal Jurisprudence, 7(1).

Beik, I. (2019). Memperkuat Peran Sukuk Negara Dalam Pembangunan Ekonomi Indonesia. Al-Infaq: Jurnal Ekonomi Islam, 2(2).

Datuk, B. (2014). Sukuk, dimensi baru pembiayaan pemerintah untuk pertumbuhan ekonomi. JRAB: Jurnal Riset Akuntansi \& Bisnis, 14(1).

EoDB Ekon. (2019, April 26). Doing Business Indonesia Kemudahan Berusaha Di Indonesia. Retrieved from Indikator Getting Electricity: eodb.ekon.go.id/indikator-eodb/gettingelectricity-2017-2/

Futurum Corporate Finance Stategists. (2019, April 26). Futurum . Retrieved from PENGENALAN PROJECT FINANCE BAGIAN 1 : KONSEP, PIHAK YANG TERLIBAT DAN ALOKASI RESIKO PADA PROJECT FINANCE: https://futurumcorfinan.com/articlevideo/futurum-pengenalan-project-finance-bagian-1/

Futurum Corporate Finance Stategists. (2019, April 26). Futurum . Retrieved from PENGENALAN PROJECT FINANCE BAGIAN 2 : ALOKASI RESIKO, TAHAPAN DALAM PROJECT FINANCE DAN PERANAN FINANCIAL MODELING: https://futurumcorfinan.com/article-video/futurum-pengenalan-project-finance-bagian-2/

Hamid, M. (2006). Membumikan Ekonomi Syariah di Indonesia (perspektif sosioyuridis). Jakarta: Elsas.

Hariyanto, E. (2016). Peluang Pembiayaan Infrastruktur Melalui Sukuk Negara. Direktorat Jenderal Pengelolaan Utang Kementerian Keuangan.

Hastuti, E. (2018). Sukuk Tabungan: Investasi Syariah Pendorong Pembangunan Ekonomi Inklusif. Jurnal Jurisprudence, 7(2).

Kementrian Keuangan Republik Indonesia. (2019, April 26). Kementerian Keuangan Republik Indonesia. Retrieved from Sukuk Tabungan: https://www.kemenkeu.go.id/sukuktabungan

Kotler, P. (2002). Manajemen Pemasaran (2 ed.). Millennium.

Setiadi, W. (2018). Simplifikasi Peraturan Perundang-undangan Dalam Rangka Mendukung Kemudahan Berusaha. Jurnal RechtsVinding, 7(3). 
Fadzlurrahman \& Lastuti Abubakar

World Bank Group. (2019). “Doing Business 2019”, A World Bank Group Flagship Report. World Bank Group. 